\title{
Evaluation of the Potential Ecological Risk of Heavy Metal Pollution in Soil and Bioaccumulation Characteristics of Dominant Plants in Siding $\mathrm{Pb}-\mathrm{Zn}$ Mineland
}

\author{
Lee Jincheng, Wang Fen, Xu Zhifen, Liu Jie, Xu Dandan, Yin Renzhan \\ Department of Environmental Science and Engineering \\ Guilin University of Technology \\ Guilin, 541004 \\ china_ljc@263.net
}

\begin{abstract}
Soils and dominant plants were surveyed in the Siding mineland area. Based on the determination of heavy metal concentration of soil from 8 sections and 14 dominant plant species in different parts, the potential ecological risk was assessed using the Hakanson Index Method. The results indicated that the soil of Siding mineland area was seriously contaminated by $\mathrm{Pb}$ and $\mathrm{Zn}$. The risk index values of $P b$ and $Z n$ were higher than 320, and the degree of ecological hazard was extremely high. While the risk index values of $\mathrm{Cu}$ and $\mathrm{Cr}$ were lower than 40, and the degree of ecological hazard was low. Statistical analyses showed that mining and smelt activities had a great influence on the concentration and distribution of heavy metals. $\mathrm{Pb}-\mathrm{Zn}$ and $\mathrm{Pb}-\mathrm{Cu}$ were likely from a same source, while $\mathrm{Cr}$ had a different cumulating character. Furthermore, $\mathrm{Pb}, \mathrm{Zn}, \mathrm{Fe}, \mathrm{Mn}, \mathrm{Cu}$ and $\mathrm{Cr}$ in 14 dominant plant species were at different levels. But the heavy metal concentrations of aboveground part had not reached the level for hyperaccumulators. Among all the dominant plants, Phragmites australis (Cav) Trin.ex Steud., Imperata cylindrical (Linn.) Beauv., Herba taraxaci and Peris vittata L. appeared to have good accumulation of $P b$ and $Z n$, and would be very useful in the restoration of $P b$ and $Z n$ contaminated areas.
\end{abstract}

Keywords-heavy metal pollution;ecological risk; hyperaccumulator; Siding Pb-Zn mineland area insert

\section{INTRODUCTION}

There is a dense distribution of non-ferrous metal minelands in south China. The mining activities started long time ago and were intensive. As the mineral resources can't be removed, it brought about a series of social economic and ecological problems, such as long time of occupying, destroying and polluting lands (Luo, et al., 2007). These all changed the aqueous and thermal structures and destroyed the areas and systems for animals and plants. Heavy metal pollution exists universally and is most series (Pen, et al., 2005). It not only limited the development of the mine, but also influenced the agricultural production and inhabitant health around minelands. Siding is the large-scale of state multi-metal mine in China, with the area of $13.64 \mathrm{~km}^{2}$. It was finished and put into production in February 1960. Until now, the heartland of the mine had been mining up, left only sporadic mine operating around it.

This work investigated and analyzed the heavy metal concentrations in soils and dominant plant accumulation in Siding minelands. Using the Hakanson Index Method, the potential ecological risk of heavy metal pollution was also evaluated. The understanding of bioaccumulation characteristics of dominant plants will be useful for heavy metal pollution, scientific management, phytoremediation and ecological restoration.

\section{MATERIALS AND METHODS}

\section{A. The survey site}

The geography coordinate center of Siding $\mathrm{Pb}-\mathrm{Zn}$ mineland is longitude $109^{\circ} 31^{\prime} 12^{\prime \prime} \mathrm{E}$, latitude $25^{\circ} 00^{\prime} 13$ " N, located at Guangxi Rong-an County, China. The landform there is external ring protuberant with the height more than $400 \mathrm{~m}$, and internal billabong with the height about $320 \mathrm{~m}$. The soil is subacidity ( $\mathrm{pH} \approx 6.0$ ). The good condition of aqueous and thermal structures is propitious to plant growing, which provides advantageous climate and geological condition for reclamation and environmental improvement.

\section{B. Sample collection}

Soil sampling and vegetation investigation in Siding $\mathrm{Pb}$ $\mathrm{Zn}$ mineland were carried out in March 2006. The mineland was divided into 8 areas in terms of mining and vegetation coverage (Fig.1). A area was unquarried; B area was located in sewage outfall of refinery, where there was a small river $10 \mathrm{~m}$ away. Sewage from the refinery was discharged into the river; $\mathrm{C}$ area was located in $50 \mathrm{~m}$ downstream of the sewage outfall; D area was located in sewage outfall of Laqiong village. Sewage from contaminated area flowed down hillside so that formed a contaminated area of black silt pulpy (about $300 \mathrm{~m}^{2}$ ). There was no plant in the center of the contaminated area; E area was a flat of sewage outfall at the foot of the hill; $F$ area was a tailing dam; $G$ area was a pithead tailing dam; $H$ 
area have been used for reclamation for 5 years. For each area,

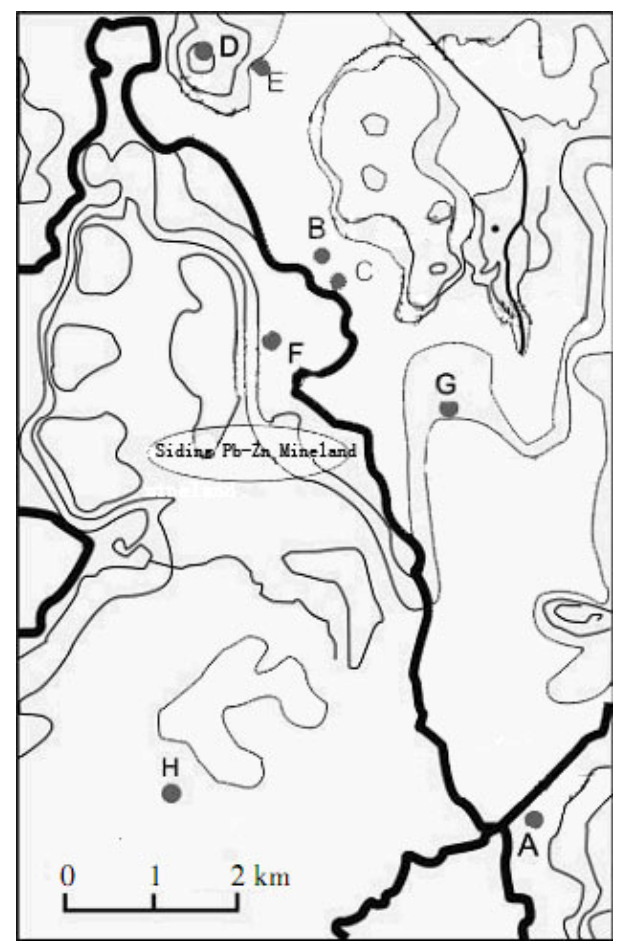

Figure 1. Positions of sampling sites

3 samples were collected randomly (3-5 subsamples were merged into one single sample with the sampling depth of $20 \mathrm{~cm})$. There were 24 soil samples in all. According to the growing situation, the dominant plants were sampled. All soil and plant samples were sealed with polythene bags and transported into laboratory.

\section{Soil and plant analysis}

Soil samples were air-dried, ground and passed through a 100 mesh plastic sieve. Plant samples were gently washed with tap water and then rinsed with deionized water. Than they were put into an oven with $105^{\circ} \mathrm{C}$ for $30 \mathrm{~min}$ and $70^{\circ} \mathrm{C}$ for 24 hours. Dried plant tissues were ground into fine powder. Soil samples were digested with concentrated $\mathrm{HCl}+$ concentrated $\mathrm{HNO}_{3}+\mathrm{HF}+\mathrm{HClO}_{4}(10: 5: 5: 3, \mathrm{v} / \mathrm{v})$ and plant tissues were digested with concentrated $\mathrm{HNO}_{3}$. The total metal concentrations $(\mathrm{Pb}, \mathrm{Zn}, \mathrm{Mn}, \mathrm{Cu}$ and $\mathrm{Cr})$ in digestates were then determined by a atomic absorption spectrometer (AA-700). The quality control was made by parallel samples and recovery of standard substance (GBW08303) in order to ensure the accuracy and precision.

\section{Evaluation method and standard of heavy metal pollution}

The potential ecological risk index was used for evaluation of heavy metal contamination in soil, which was suggested by Hakanson (1980) basing of heavy metal's characteristic and environmental action (Liu, et al., 2007). This method associated with heavy metal concentration, ecological effect, environmental effect and toxicology to evaluate single element or multiple elements quantitatively.
This method was also used to evaluate heavy metal pollution of sedimentation (Jia, et al., 1997; Li, et al., 2007; Ma, et al., 2003; Liu, et al., 2007; Xiang, et al., 2006). The calculation formulas are as follows:

$$
\begin{gathered}
C_{f}^{i}=C_{f}^{n} / C_{n}^{i}, \quad E_{r}^{i}=T_{r}^{i} \times C_{f}^{i} \\
R I=\sum_{i=1}^{n} E_{r}^{i}=\sum_{i=1}^{n} T_{r}^{i} \times C_{f}^{i}=\sum_{i=1}^{n} T_{r}^{i} \times C_{f}^{m} / C_{n}^{i}
\end{gathered}
$$

where $C_{f}^{i}$ is a parameter of metal pollution; $C_{f}^{n}$ is actually testing concentration of heavy metal in sedimentation; $C_{n}^{i}$ is a reference value in calculation; $E_{r}^{i}$ is a parameter of potential ecological risk; and $T_{r}^{i}$ is a parameter of toxic response by single pollutant, which can display relationships of heavy metal among aqueous phase, solid phase of sedimentation and organisms.. There were great differences in the selection of reference value among the previous works. Most of them prefer to choose average background value of heavy metal in sedimentation (Wang, et al., 2005), or background value of local soil (Wu, et al., 2007), or background value of sampling (Liu, et al., 1999). In order to evaluate the heavy metal pollution more objectively, the present work chose the background value of local soil as the reference value. The standard parameter of toxic response made by Hakanson is: $\mathrm{Zn}(1)<\mathrm{Cr}(2)<\mathrm{Cu}(5)=\mathrm{Ni}(5)=\mathrm{Pb}(5)<\mathrm{As}(10)<\mathrm{Cd}(30)<$ $\mathrm{Hg}(40)$ (Lars Hakanson, 1980). As lacking of the parameter of toxic response of $\mathrm{Mn}$, this study had not evaluated of its potential ecological risk. The grading standard of coefficients and indices of heavy metals' ecological risks was showed in table 1.

TABLE I. GRADING STANDARD OF COEFFICIENTS AND INDICES OF POTENTIAL ECOLOGICAL RISK OF HEAVY METALS

\begin{tabular}{|c|c|c|c|}
\hline Changes of $E_{r}^{i}$ & $\begin{array}{c}\text { Levels of } \\
\text { ecological } \\
\text { risks of single } \\
\text { factor }\end{array}$ & $\begin{array}{c}\text { Changes of } \\
\text { indices of } \\
\text { potential } \\
\text { ecological } \\
\text { risks }(\boldsymbol{R I})\end{array}$ & $\begin{array}{c}\text { Levels of } \\
\text { overall } \\
\text { potential } \\
\text { ecological } \\
\text { risks }\end{array}$ \\
\hline$E_{r}^{i<40}$ & Slight & $R I<150$ & slight \\
\hline $40 \leq E_{r}^{i}<80$ & medium & $150 \leq R I<300$ & medium \\
\hline $80 \leq E_{r}^{i<160}$ & strong & $300 \leq R I<600$ & strong \\
\hline $160 \leq E_{r}^{i}<320$ & very strong & $R I \geq 600$ & very strong \\
\hline$E_{r}^{i} \geq 320$ & extremely & & \\
\hline
\end{tabular}

\section{RESULTS}

\section{A. Heavy metals in soil}

The concentrations of $\mathrm{Pb}, \mathrm{Zn}, \mathrm{Mn}, \mathrm{Cu}$ and $\mathrm{Cr}$ in the soils were 5934.2, 23285.3, 447.0, 78.8 and $51.7 \mathrm{mg} / \mathrm{kg}$ (Table 2). The order of metal concentration was $\mathrm{Zn}>\mathrm{Pb}>\mathrm{Mn}>\mathrm{Cu}>\mathrm{Cr}$. The concentrations of $\mathrm{Pb}, \mathrm{Zn}, \mathrm{Mn}, \mathrm{Cu}$ in the 8 sampling areas were much higher than soil background values in both Guangxi and China, with the concentrations of $\mathrm{Pb}, \mathrm{Zn}$ higher than the Grade III of Environmental Quality Standard for soils. The concentration of $\mathrm{Pb}$ was $18212.0 \mathrm{mg} / \mathrm{kg}$, which was 
36 times to the value of Grade III of Environmental Quality Standard for soils. The highest concentration of $\mathrm{Zn}$ with $75300.9 \mathrm{mg} / \mathrm{kg}$ of tailing dam was 150 times to the value of Grade III of Environmental Quality Standard for soil. The highest concentrations of $\mathrm{Cu}$ and $\mathrm{Cr}(146.0 \mathrm{mg} / \mathrm{kg}$ and $101.0 \mathrm{mg} / \mathrm{kg}$ ) were from the sewage outfall of refinery. They were both lower than Grade II of Environmental Quality Standard for soils. As regard Mn, the highest concentration $(846.0 \mathrm{mg} / \mathrm{kg})$ appeared in the flat of the sewage outfall at the foot of the hill, which was 5-folds of soil background values in Guangxi and 1.7-folds of soil background values in China. The variation coefficients of $\mathrm{Pb}, \mathrm{Zn}$ were high, which indicated the distribution of $\mathrm{Pb}, \mathrm{Zn}$ in different sampling points was greatly different and the mining activity significantly influence the concentration and distribution of heavy metals.

\section{B. Correlations of heavy metals}

In order to realize the correlations of heavy metals, the Spearman Ranking Correlation Coefficient and Kendall $\zeta$
Correlation Coefficient were calculated (Table 3 ). The correlation between heavy metals could estimate whether they came from the same source. In natural world, heavy metal pollution is complex with several metals compound. If they significantly correlated, the possibility of homeology is grate. The source may come from natural (source of geochemistry), or compound pollution resulted from human activities (Yang, et al., 2007). The two correlation coefficients both showed that there was a significant correlation between $\mathrm{Pb}$ and $\mathrm{Zn}$, or $\mathrm{Pb}$ and $\mathrm{Cu}$ (table 3 ). Therefore, there was great possibility of their homeology, and in accordance with reality. In addition, the Spearman Ranking Correlation Coefficient showed that there was a very significantly correlation between $\mathrm{Cu}$ and $\mathrm{Zn}$, while the Kendall $\zeta$ Correlation Coefficient also displayed significant correlation. The results showed that the two calculating methods were consistent. The correlation between $\mathrm{Cr}$ and other heavy metals was low, indicating special accumulation of $\mathrm{Cr}$.

TABLE II. HEAVy METAL CONCENTRATIONS IN SOIL AND SLAG OF SidING PB-ZN MINELAND

\begin{tabular}{|c|c|c|c|c|c|}
\hline Sampling points & $\mathbf{P b}$ & $\overline{Z n}$ & Mn & $\mathbf{C u}$ & $\mathbf{C r}$ \\
\hline A & $1420.0 \pm 104.6$ & $3236.0 \pm 283.1$ & $214.0 \pm 21.4$ & $36.0 \pm 4.6$ & $50.0 \pm 3.0$ \\
\hline B & $18212.0 \pm 2121.6$ & $32375.0 \pm 3410.8$ & $310.0 \pm 45.2$ & $146.0 \pm 22.5$ & $101.0 \pm 14.3$ \\
\hline $\mathrm{C}$ & $3021.8 \pm 132.3$ & $26889.9 \pm 244.3$ & $313.9 \pm 19.0$ & $82.6 \pm 7.3$ & $16.1 \pm 1.1$ \\
\hline $\mathrm{D}$ & $5138.0 \pm 341.7$ & $14041.0 \pm 2953.0$ & $596.0 \pm 33.9$ & $109.0 \pm 27.2$ & $67.0 \pm 13.3$ \\
\hline $\mathrm{E}$ & $1746.0 \pm 87.2$ & $4500.0 \pm 144.3$ & $846.0 \pm 26.0$ & $48.0 \pm 8.6$ & $59.0 \pm 6.5$ \\
\hline $\mathrm{F}$ & $9821.5 \pm 128.8$ & $75300.9 \pm 1636.6$ & $838.0 \pm 56.7$ & $119.8 \pm 14.3$ & $29.6 \pm 5.1$ \\
\hline G & $6614.0 \pm 175.2$ & $26500.0 \pm 1232.0$ & $246.0 \pm 23.1$ & $56.0 \pm 11.7$ & $46.0 \pm 5.5$ \\
\hline $\mathrm{H}$ & $1500.0 \pm 181.8$ & $3440.0 \pm 263.2$ & $212.0 \pm 22.4$ & $33.0 \pm 5.7$ & $45.0 \pm 9.3$ \\
\hline Average value & 5934.2 & 23285.3 & 447.0 & 78.8 & 51.7 \\
\hline Standard deviation & 5769.6 & 24040.8 & 272.7 & 42.3 & 25.5 \\
\hline Variation coefficient $(\%)$ & 97.2 & 103.2 & 61.0 & 53.7 & 49.3 \\
\hline $\begin{array}{c}\text { Soil background values in } \\
\text { Guangxi }\end{array}$ & 18.82 & 46.43 & 172.57 & 20.79 & 56.25 \\
\hline $\begin{array}{l}\text { Soil background values in } \\
\text { China }\end{array}$ & 24.00 & 67.40 & 482.00 & 20.00 & 54.10 \\
\hline $\begin{array}{c}\text { Grade II of } \\
\text { Environmental Quality } \\
\text { Standard for soil }\end{array}$ & 250 & 200 & - & 150 & 150 \\
\hline $\begin{array}{c}\text { Grade III of } \\
\text { Environmental Quality } \\
\text { Standard for soil }\end{array}$ & 500 & 500 & - & 400 & 300 \\
\hline
\end{tabular}


TABLE III. SPEARMAN AND KENDALl Z CORRELATION COEFFICIENTS OF HEAVY METALS

\begin{tabular}{|c|c|c|c|c|c|}
\hline & Coefficients & $\mathbf{P b}$ & $\mathbf{Z n}$ & Mn & $\mathrm{Cu}$ \\
\hline \multirow{2}{*}{ Zn } & Spearman & $0.905(* *)$ & & & \\
\hline & Kendall $\zeta$ & $0.786(* *)$ & & & \\
\hline \multirow{2}{*}{ Mn } & Spearman & 0.357 & 0.452 & & \\
\hline & Kendall & 0.214 & 0.286 & & \\
\hline \multirow{2}{*}{$\mathbf{C u}$} & Spearman & $0.905(* *)$ & $0.881(* *)$ & 0.500 & \\
\hline & Kendall & $0.786(* *)$ & $0.714(*)$ & 0.429 & \\
\hline \multirow{2}{*}{$\mathrm{Cr}$} & Spearman & 0.190 & -0.167 & 0.095 & 0.238 \\
\hline & Kendall $\zeta$ & 0.143 & -0.071 & 0.071 & 0.214 \\
\hline
\end{tabular}

\section{Evalution of the potential ecological risk of heavy metal pollution}

Potential ecological risk indexes of single $\left(E_{r}^{i}\right)$ and multiple $(R I)$ heavy metals of Siding $\mathrm{Pb}-\mathrm{Zn}$ mineland were in table 4 . The potential ecological risk indexes ranged from 377.3 to 4838.5 for $\mathrm{Pb}$, from 69.7 to 1621.6 for $\mathrm{Zn}$, from 7.9 to 35.1 for $\mathrm{Cu}$, and from 0.6 to 2.4 for $\mathrm{Cr}$. So the corresponding potential ecological risk levels were: very strong of $\mathrm{Pb} 、 \mathrm{Zn}$, slight of $\mathrm{Cu} 、 \mathrm{Cr}$. The trend of potential ecological risk of this 4 heavy metals was: $E_{r}^{i}(\mathrm{~Pb})>E_{r}^{i}(\mathrm{Zn})>$ $E_{r}^{i}(\mathrm{Cu})>E_{r}^{i}(\mathrm{Cr})$.

$R I$ of 8 sampling areas were all above 300 (table 4 ), which indicated that potential ecological risk in each area was strong. The order of the ecological risk level was: $\mathrm{B}>\mathrm{F}>\mathrm{G}>$ $\mathrm{D}>\mathrm{C}>\mathrm{E}>\mathrm{H}>\mathrm{A}$. It meaned: sewage outfall of refinery $>$ tailing dam $>$ pithead tailing dam $>$ sewage outfall of Laqiong village $>50$ meters downstream of the sewage outfall $>$ reclaimed area $>$ unquarried area. The result showed that waste water and residue from smelting were main pollution sources in Siding mineland. The potential ecological risk of surrounding area of sewage outfall even exceeded that of tailing dam. Therefore, management must be strict and audit to cleaning production of processing heavy metals ought to be strengthened.

\section{Community analyze of dominant plants}

In Siding mineland, 14 species of higher plants that belonged to 11 families, including 3 gramineae and 2 euphorbiaceae, had been investigated. The main artificial cultivated plants were fruit trees, vegetables and cash crops. Dominant species were almost herbaceous plant and mainly belonged to gramineae, which due to their abundant species, fast growing, widely distribution and resistant of arid and dry.

TABLE IV. POTENTIAL ECOLOGICAL RISK FACtor $\left(E_{r}^{i}\right)$ AND POTENTIAL ECOLOGICAL RISK INDEX $(R I)$ OF HEAVY METALS IN SIDING PB-ZN MINELAND

\begin{tabular}{|c|c|c|c|c|c|}
\hline \multirow[t]{2}{*}{ Areas } & \multicolumn{4}{|c|}{$E_{r}^{i}$} & \multirow{2}{*}{$R I$} \\
\hline & $P b$ & $Z n$ & $\mathrm{Cu}$ & $\mathrm{Cr}$ & \\
\hline$A$ & 377.3 & 69.7 & 8.7 & 1.8 & 457.4 \\
\hline$B$ & 4838.5 & 697.3 & 35.1 & 3.6 & 5574.5 \\
\hline$C$ & 802.8 & 579.1 & 19.9 & 0.6 & 1402.4 \\
\hline$D$ & 1365.0 & 302.4 & 26.2 & 2.4 & 1696.0 \\
\hline$E$ & 463.9 & 96.9 & 11.5 & 2.1 & 574.4 \\
\hline$F$ & 2609.3 & 1621.8 & 28.8 & 1.1 & 4261.0 \\
\hline$G$ & 1757.2 & 570.8 & 13.5 & 1.6 & 2343.0 \\
\hline$H$ & 398.5 & 74.1 & 7.9 & 1.6 & 482.1 \\
\hline Average values $\left(E_{r}^{i}\right)$ & 1448.2 & 471.7 & 25.6 & 1.7 & \\
\hline
\end{tabular}

TABLE V. DOMINANT SPECIES OF PLANTS IN SIDING PB-ZN MINELAND

\begin{tabular}{|c|c|c|c|}
\hline Families & Species & Abundance & Life form \\
\hline Gramineae & Imperata cylindrica (Linn.) Beauv. & F & Perennial herb \\
\hline Gramineae & $\begin{array}{c}\text { Phragmites australis (Cav.) } \\
\text { Trin. ex Steud. }\end{array}$ & D & Perennial herb \\
\hline Moraceae & Ficus tikoua & F & Prostrate woody vine \\
\hline Labiatae & $\begin{array}{c}\text { Dysophylla } \\
\text { EI-Gazzar et L. Wats. ex Airy shaw }\end{array}$ & Annal forb \\
\hline
\end{tabular}




\begin{tabular}{|c|c|c|c|}
\hline Pteridacea & Pteris vittata $\mathrm{L}$. & $\mathrm{F}$ & Perennial herb \\
\hline Rosaceae & Rosa laevigata Michx. & $\mathrm{F}$ & Shrub \\
\hline Euphorbiaceae & $\begin{array}{l}\text { Alchornea trewioides (Benth.) } \\
\text { Muell. Arg. }\end{array}$ & $\mathrm{F}$ & Shrub \\
\hline Equisetaceae & Equisctum ramosissimum Desf. & $\mathrm{D}$ & Perennial herb \\
\hline Euphorbiaceae & $\begin{array}{c}\text { Drypetes cumingii (Baill.) Pax et } \\
\text { Hoffm }\end{array}$ & $\mathrm{F}$ & Shrub \\
\hline Compositae & Herba Taraxaci & $\mathrm{F}$ & Perennial herb \\
\hline Gramineae & Miscanthus floridulus & $\mathrm{D}$ & Perennial herb \\
\hline Compositae & Ageratum conyzoides L. & $\mathrm{F}$ & Annual forb \\
\hline Loganiaceae & Flos Buddlejae & $\mathrm{O}$ & Sheepberry \\
\hline Cruciferae & Beassica pekinensis (Lour.) Rupr. & $\mathrm{F}$ & Annual forb \\
\hline
\end{tabular}

\section{E. Concentrations of heavy metals in dominant plants}

In order to study the absorption and accumulation to $\mathrm{Pb}$, $\mathrm{Zn}, \mathrm{Mn}, \mathrm{Cu}$ and $\mathrm{Cr}$ by dominant plants quantitatively and to find accumulators with heavy metal resistance, the concentrations of heavy metals in dominant plants were analyzed. The accumulated ability of plants is depended on biological features of the plants, soil types, nutrient elements and heavy metal availability. Table 6 presented the accumulation of heavy metals by 14 dominant plants, with the concentration range was: $\mathrm{Pb} 15.24 \sim 1496.0 \mathrm{mg} / \mathrm{kg}, \mathrm{Zn} 110$. $20 \sim 20425.3 \mathrm{mg} / \mathrm{kg}, \quad \mathrm{Mn} \quad 4.6 \sim 282.9 \mathrm{mg} / \mathrm{kg}, \quad \mathrm{Cu}$ $1.6 \sim 285.9 \mathrm{mg} / \mathrm{kg}, \mathrm{Cr} 1.0 \sim 152.3 \mathrm{mg} / \mathrm{kg}$. Compared with the normal concentration in plant, only the concentration of $\mathrm{Mn}$ was in normal range.

Concentrations of $\mathrm{Pb}, \mathrm{Zn}$ in all plants were in the normal level. But they unreached to the critical concentrations $(1000 \mathrm{mg} / \mathrm{kg}$ and $10000 \mathrm{mg} / \mathrm{kg})$ (Baker, et al., 1983) of the hyperaccumulator. Concentrations of $\mathrm{Pb}, \mathrm{Zn}$ in root of Pteris vittata L. were $467.93 \mathrm{mg} / \mathrm{kg}$ and $20425.31 \mathrm{mg} / \mathrm{kg}$. Meanwhile, concentrations in its stem and leaf were $536.62 \mathrm{mg} / \mathrm{kg}$ and $2537.56 \mathrm{mg} / \mathrm{kg}$. It proved that Pteris vittata L. had a good toxic resistance of $\mathrm{Pb}, \mathrm{Zn}$, that was accordance with the study by An et al (2007). Ageratum conyzoides L. had a concentration of $703.14 \mathrm{mg} / \mathrm{kg}$ of $\mathrm{Pb}$ in the stem and leaf, which closed to $1000 \mathrm{mg} / \mathrm{kg}$. Further research could be carried out to study its potential accumulation.

As to $\mathrm{Cu}$, concentrations with $285.91 \mathrm{mg} / \mathrm{kg}$ and $47.07 \mathrm{mg} / \mathrm{kg}$ in root and leaf of Pteris vittata L. in the sewage outfall of Laqiong village exceeded the normal level. And concentrations of other plants were all in normal level.

To Cr, only concentration of Drypetes cumingii (Baill.) Pax et Hoffm which grew in downstream of the sewage outfall of Laqiong village was in normal level, while others' all exceeded. But they were below the critical concentration of hyperaccumulator $(1000 \mathrm{mg} / \mathrm{kg})$.

\section{F. Accumulation and transfer characteristics by different plants}

The concept of hyperaccumulator was proposed by Brooks in 1977 (Brooks, et al., 1977). Plants ideal for phytoremediation should posses multiple traits. They must have short growing period, resistance of plant diseases and insect pests, large biomass of aboveground part, and accumulate more than two heavy metals simultaneously.

To known the accumulation ability of plants further, Biological Accumulation Coefficient (BAC) and Biological Transfer Coefficient (BTC) were calculated (Table 7). BAC represents accumulation of one heavy metal (Salt, et al., 1995). As easy to collect, the aboveground part of plant is important in actual soil heavy metal remediation. It is that, larger the BAC, stronger the ability of accumulating heavy metals. BAC of aboveground part of plant larger than 1 is a prominent feature that to distinct the hyperaccumulator from other plants. BTC can reflect the plant ability of transferring heavy metals from root to their aboveground part. Heavy metal concentration in root is usually much higher than that in stem and leaf. But in hyperaccumulator, situation can be opposite. Generally, there should be more ionic transfer or channel protein to promote heavy metals loading to xylem (Wu, et al., 2007). As presented in table 7, BAC of Pteris vittata $\mathrm{L}$. for $\mathrm{Cr}$ was 2.27. However, Pteris vittata $\mathrm{L}$. was not a hyperaccumulator for $\mathrm{Cr}$ due to the $\mathrm{Cr}$ concentration (141.7 $\mathrm{mg} / \mathrm{kg}$ ) in the plant could not meet the critical level of $1000 \mathrm{mg} / \mathrm{kg}$. Plants with stronger ability of $\mathrm{Pb}$ accumulation were Phragmites australis (Cav.) Trin. Ex Steud. (BAC=0.4) and Ageratum conyzoides L. $(\mathrm{BAC}=0.37)$. Plants with stronger ability of $\mathrm{Zn}$ accumulation was Imperata cylindrica (Linn.) Beauv. (BAC $=0.47$ ). Plants with stronger ability of $\mathrm{Cu}$ accumulation were Pteris vittata $\mathrm{L} .(\mathrm{BAC}=0.43)$ and Herba Taraxaci $(\mathrm{BAC}=0.46)$. Plants with stronger ability of $\mathrm{Cr}$ accumulation were Pteris vittata $\mathrm{L}$. $(\mathrm{BAC}=2.27)$ and Ficus tikoua $(\mathrm{BAC}=0.54)$. Plants with stronger ability of $\mathrm{Mn}$ accumulation was Phragmites australis (Cav.) Trin. Ex Steud. $(\mathrm{BAC}=0.47)$. 
TABLE VI. HEAVY METAL CONCENTRATIONS OF THE DOMINANT SPECIES IN SIDING PB-ZN MINELAND (MG/KG)

\begin{tabular}{|c|c|c|c|c|c|c|c|}
\hline Species & areas & Tissue & $\mathbf{P b}$ & Zn & $\mathbf{C u}$ & $\mathrm{Cr}$ & Mn \\
\hline Imperata cylindrica (Linn.) Beauv. & A & Root & 758.60 & 3989.00 & 44.32 & 32.33 & 50.06 \\
\hline & & Stem & 189.64 & 1516.05 & 12.41 & 24.25 & 33.54 \\
\hline \multirow[t]{3}{*}{ Phragmites australis (Cav.) Trin. Ex Steud. } & $\mathrm{B}$ & Root & 148.45 & 1310.91 & 23.13 & 8.47 & 8.23 \\
\hline & & Stem & 93.12 & 1462.53 & 17.05 & 9.10 & 7.06 \\
\hline & & Leaf & 578.10 & 500.00 & 17.64 & 14.25 & 10.02 \\
\hline \multirow[t]{3}{*}{ Ficus tikoua } & $\mathrm{B}$ & Root & 562.96 & 1549.90 & 19.52 & 59.80 & 179.46 \\
\hline & & Stem & 523.29 & 1063.16 & 19.54 & 41.51 & 123.45 \\
\hline & & Leaf & 438.32 & 1112.62 & 11.94 & 40.07 & 120.49 \\
\hline \multirow[t]{2}{*}{ Dysophylla } & $\mathrm{B}$ & Root & 513.15 & 1988.97 & 63.76 & 57.44 & 282.89 \\
\hline & & Stem & 112.71 & 303.10 & 4.74 & 29.95 & 80.18 \\
\hline \multirow[t]{2}{*}{ Pteris vittata $L}$. & $\mathrm{D}$ & Root & 467.93 & 20425.31 & 285.91 & 141.71 & 160.52 \\
\hline & & Stem and leaf & 536.62 & 2537.56 & 47.07 & 152.32 & 56.49 \\
\hline \multirow[t]{3}{*}{ Rosa laevigata Michx. } & $\mathrm{D}$ & Root & 1285.35 & 13400.11 & 26.13 & 4.18 & 23.64 \\
\hline & & Stem & 256.07 & 587.54 & 16.46 & 14.78 & 18.05 \\
\hline & & Leaf & 126.54 & 550.20 & 13.37 & 26.54 & 41.04 \\
\hline \multirow[t]{3}{*}{ Alchornea trewioides (Benth.) Muell. Arg. } & $\mathrm{D}$ & Root & 378.17 & 637.55 & 15.64 & 8.52 & 29.93 \\
\hline & & Stem & 340.06 & 562.52 & 18.65 & 6.33 & 25.37 \\
\hline & & Leaf & 164.00 & 662.50 & 12.30 & 20.30 & 30.60 \\
\hline \multirow[t]{2}{*}{ Equisctum ramosissimum Desf. } & $\mathrm{D}$ & Root & 151.60 & 1250.0 & 18.49 & 33.32 & 53.09 \\
\hline & & Stem and leaf & 103.10 & 575.00 & 8.32 & 9.33 & 27.61 \\
\hline \multirow[t]{2}{*}{ Drypetes cumingii (Baill.) Pax et Hoffm } & $\mathrm{D}$ & Root & 959.50 & 2325.0 & 12.91 & 140.31 & 59.07 \\
\hline & & Stem & 110.71 & 300.00 & 7.64 & 7.15 & 17.15 \\
\hline \multirow[t]{3}{*}{ Herba Taraxaci } & $\mathrm{F}$ & Root & 23.22 & 125.00 & 8.98 & 4.41 & 4.67 \\
\hline & & Stem & 35.84 & 263.94 & 21.84 & 36.84 & 10.64 \\
\hline & & Leaf & 86.03 & 875.03 & 13.18 & 15.68 & 15.84 \\
\hline \multirow[t]{2}{*}{ Miscanthus floridulus } & $\mathrm{F}$ & Root & 217.46 & 1230.85 & 16.22 & 30.81 & 33.93 \\
\hline & & Stem & 342.52 & 1162.57 & 7.14 & 51.45 & 33.66 \\
\hline \multirow[t]{2}{*}{ Ageratum conyzoides $L$. } & $\mathrm{F}$ & Root & 1496.0 & 4079.0 & 23.96 & 32.60 & 51.22 \\
\hline & & Stem and leaf & 703.14 & 1550.04 & 11.50 & 21.84 & 39.95 \\
\hline \multirow[t]{2}{*}{ Flos Buddlejae } & G & Root & 792.81 & 2500.0 & 17.46 & 9.94 & 30.33 \\
\hline & & Stem & 495.02 & 1437.52 & 14.05 & 4.42 & 20.03 \\
\hline
\end{tabular}




\begin{tabular}{|c|c|c|c|c|c|c|c|}
\hline & & Leaf & 305.30 & 1300.02 & 15.83 & 23.10 & 30.52 \\
\hline Beassica pekinensis (Lour.) Rupr. & $\mathrm{H}$ & Root & 54.42 & 343.80 & 5.64 & 3.78 & 23.77 \\
\hline & & Stem and leaf & 15.24 & 110.20 & 1.58 & 1.02 & 5.23 \\
\hline Normal concentration & & & $0.1 \sim 41.7$ & $1 \sim 160$ & $0.4 \sim 45.8$ & $0 \sim 8.4$ & $1 \sim 700$ \\
\hline
\end{tabular}

TABLE VII. The BIOlogical ACCUMUlation COEFFICIENT (BAC) AND BIOLOGICAL TRANSFER COEFFICIENT (BTC) OF THE DOMINANT SPECIES IN SIDING PB-ZN MINELAND

\begin{tabular}{|c|c|c|c|c|c|c|c|c|c|c|c|}
\hline \multirow{2}{*}{ Species } & \multirow{2}{*}{ Sampling area } & \multicolumn{2}{|c|}{$\mathbf{P b}$} & \multicolumn{2}{|c|}{$\mathbf{Z n}$} & \multicolumn{2}{|c|}{$\mathbf{C u}$} & \multicolumn{2}{|c|}{$\mathrm{Cr}$} & \multicolumn{2}{|c|}{ Mn } \\
\hline & & $B A C$ & BTC & $B A C$ & BTC & $B A C$ & BTC & $B A C$ & BTC & $B A C$ & BTC \\
\hline Imperata cylindrica (Linn.) Beauv. & A & 0.13 & 0.25 & 0.47 & 0.38 & 0.34 & 0.28 & 0.49 & 0.75 & 0.16 & 0.67 \\
\hline Ficus tikoua & B & 0.10 & 0.85 & 0.06 & 0.70 & 0.10 & 0.81 & 0.54 & 0.68 & 0.11 & 0.68 \\
\hline Dysophylla & $\mathrm{B}$ & 0.32 & 0.22 & 0.01 & 0.15 & 0.02 & 0.07 & 0.01 & 0.52 & 0.15 & 0.28 \\
\hline Phragmites australis (Cav.) Trin. Ex Steud. & B & 0.40 & 0.22 & 0.40 & 0.50 & 0.07 & 0.44 & 0.01 & 0.86 & 0.47 & 0.15 \\
\hline Pteris vittata $L$. & $\mathrm{D}$ & 0.10 & 1.15 & 0.18 & 0.12 & 0.43 & 0.16 & 2.27 & 1.07 & 0.09 & 0.35 \\
\hline Rosa laevigata Michx. & $\mathrm{D}$ & 0.04 & 0.15 & 0.04 & 0.04 & 0.14 & 0.57 & 0.31 & 4.94 & 0.05 & 1.25 \\
\hline Alchornea trewioides (Benth.) Muell. Arg. & $\mathrm{D}$ & 0.05 & 0.67 & 0.04 & 0.96 & 0.14 & 0.99 & 0.20 & 1.56 & 0.05 & 0.94 \\
\hline Equisctum ramosissimum Desf. & $\mathrm{D}$ & 0.06 & 0.68 & 0.13 & 0.46 & 0.17 & 0.45 & 0.16 & 0.28 & 0.03 & 0.52 \\
\hline Drypetes cumingii (Baill.) Pax et Hoffm & $\mathrm{D}$ & 0.06 & 0.12 & 0.07 & 0.13 & 0.16 & 0.59 & 0.12 & 0.05 & 0.02 & 0.29 \\
\hline Herba Taraxaci & $\mathrm{F}$ & 0.03 & 2.62 & 0.06 & 4.56 & 0.46 & 1.95 & 0.24 & 5.95 & 0.02 & 2.84 \\
\hline Ficus tikoua & $\mathrm{F}$ & 0.06 & 0.21 & 0.05 & 0.25 & 0.10 & 0.28 & 0.04 & 0.15 & 0.04 & 0.64 \\
\hline Miscanthus floridulus & $\mathrm{F}$ & 0.17 & 1.49 & 0.12 & 0.94 & 0.19 & 0.44 & 0.46 & 1.67 & 0.05 & 0.99 \\
\hline Ageratum conyzoides $L$. & $\mathrm{F}$ & 0.37 & 0.47 & 0.17 & 0.38 & 0.30 & 0.48 & 0.20 & 0.67 & 0.06 & 0.78 \\
\hline Flos Buddlejae & G & 0.06 & 0.50 & 0.05 & 0.55 & 0.27 & 0.86 & 0.30 & 1.38 & 0.10 & 0.83 \\
\hline Pteris vittata $L$. & $\mathrm{G}$ & 0.11 & 2.63 & 0.10 & 0.16 & 0.25 & 0.31 & 0.18 & 0.10 & 0.17 & 0.41 \\
\hline Chinese cabbage & $\mathrm{H}$ & 0.01 & 0.28 & 0.03 & 0.32 & 0.05 & 0.28 & 0.02 & 0.27 & 0.02 & 0.22 \\
\hline
\end{tabular}

$\mathrm{BAC}=($ heavy metal concentration in aboveground part of plant)/( heavy metal concentration of soil), $\mathrm{BTC}=$ (heavy metal concentration in aboveground part of plant)/(heavy metal concentration in root of plant)

When BTC was concerned, it seemed that Pteris vittata L. and Herba Taraxaci had a higher $\mathrm{Pb}$ transfer rate. Rosa laevigata Michx. and Phragmites australis (Cav.) Trin. Ex Steud. had a higher $\mathrm{Cr}$ transfer rate. And Rosa laevigata Michx. also had good Mn transfer ability. Herba Taraxaci showed good relocation abilities of $\mathrm{Pb}, \mathrm{Zn}, \mathrm{Cu}, \mathrm{Cr}$, $\mathrm{Mn}$ with BTCs larger than 1.

In all investigated plants, no hyperaccumulators had been find. However, some dominant plants in mineland such as Pteris vittata L., Imperata cylindrical (Linn.) Beauv., Ageratum conyzoides L., Herba Taraxaci) displayed good resistance to heavy metals. These species can be uesed as the pioneers for ecological restoration of mineland in early period, which can not only promote the vegetation coverage rate quickly and conserve water and soil, but also accumulate some of heavy metals.

\section{CONCLUSIONS}

The heavy metal concentrations were very high in mineland siol. Most of them were exceeded the soil critical concentration for agricultural and forestry production and plant normal growth. There were significant differences among heavy metal concentrations. Heavy metal pollution in
$\mathrm{Pb}$ mineland soil was serious, with the major pollution factors of $\mathrm{Pb}$ and $\mathrm{Zn}$. Significant correlations between $\mathrm{Pb}-\mathrm{Zn}, \mathrm{Pb}-\mathrm{Cu}$ and $\mathrm{Cu}-\mathrm{Zn}$ illustrated their possibility of homology. This was accordance with the conclusion of Baoshan $\mathrm{Pb}-\mathrm{Zn}$ mineland studied by Yue (2004). There was significant positive correlation between $\mathrm{Pb}-\mathrm{Cu}$, and very significant positive correlation among $\mathrm{Cu}, \mathrm{Pb}, \mathrm{Zn}$ (Yue, 2004). The correlation between $\mathrm{Cr}$ and other heavy metals was not obvious. This was a proof of the special accumulation of $\mathrm{Cr}$.

Evaluation of the potential ecological risk of heavy metal pollution showed that pollution of $\mathrm{Pb}, \mathrm{Zn}$ was serious in Siding mineland. The trend of pollution situation followed the order: sewage outfall of refinery $>$ tailing dam $>$ pithead tailing dam $>$ sewage outfall of Laqiong village $>50$ meters downstream of the sewage outfall $>$ reclaimed area $>$ unquarried area. Pollution in sewage outfall of refinery was the most seriously because the sewage discharged into rivers nearby. Therefore, the government department should control more strictly in order to make sewage discharge meet the standard. The ecological risk of reclaimed area was light. In other words, after reclaimation, the heavy metal pollution situation in mineland was a bit abated. 
Investigation of dominant plants in mineland indicated that different plants had significant differences of the same heavy metal absorption. And different parts of one plant also had differences to heavy metal absorption, with root $>$ stem $>$ leaf usually. Although concentrations of $\mathrm{Pb}, \mathrm{Zn}$ were high in mineland, plant accumulation was not ideal, with BACs lower than 0.5 on the whole. This was in accordance with the study of $\mathrm{Pb}-\mathrm{Zn}$ mineland in Zhejiang by $\mathrm{Bi} \mathrm{De}(\mathrm{Bi}$, et al., 2006). That was to say, plants in $\mathrm{Pb}-\mathrm{Zn}$ mineland surely had some resistance to $\mathrm{Pb}$. Even though, accumulation of all investigated plants did not meet the critical concentrations of hyperaccumulator, they were all dominant plants in local with large biomass and heavy metal resistance. Phragmites australis (Cav.) Trin. Ex Steud., Imperata cylindrica (Linn. ) Beauv., Herba Taraxaci and Pteris vittata L. had obvious $\mathrm{Pb}$ and $\mathrm{Zn}$ accumulation, and can be used as pioneer plants for ecological restoration in $\mathrm{Pb}-\mathrm{Zn}$ mineland.

\section{REFERENCES}

[1] LUO Ya-ping, WU Xiao-fu, LI Ming-shun, et al. Investigation of main plant species and assessment of soil heavy metal pollutions in manganese mine wastelands in north Guangxi[J]. Ecology and Environment, 2007, 16 (4) : 1149-1153.

[2] PENG Jian, JIANG Yi-jun, WU Jian-sheng, et al. Eco-environmental effects of mining and related land reclamation technologies in china[J]. Progress in Geography, 2005, 24 (2) : 38-48.

[3] LIU Jing, TENG Yan-guo, CUI Yan-fang, et al. Review in ecological risk assessment methods for heavy metal polluted soil[J]. The Administration and Technique of Environmental Monitoring, 2007, 19 (3) : 6-11.

[4] JIA Zhen-bang, LIANG Tao, LIN Jian-zhi, et al. Study on heavy metal contamination and potential ecological risk in Hong Kong rivers[J]. Universitatis Pekinensi, 1997, 33 (4) : 485-492.

[5] LI Gui-hai, LAN Dong-zhao, CAO Zhi-min, et al. Specificity and potential ecological risks of heavy metals in the sediments of the Xiamen sea area[J]. Journal of Marine Science Bulletin, 2007, 26 (1) : 67-72.

[6] MA De-yi, WANG Ju-ying. Evaluation on potential ecological risk of sediment pollution in main estuaries of China[J]. China Environmental Science, 2003, 23 (5) : 521-525.

[7] LIU Meng-lan, ZHENG Xi-lai, LIN Duan, et al. Enrichment of heavy metals in the surface sediments from the three regions of random dumping in South China Sea and assessment of their potential ecological risk[J]. Marine Environmental Science, 2007, 26 (2) : 158-165.

[8] XIANG Yong, MIAO Qi-long, FENG Jiang-fan, et al. Pollution of heavy metals in the bottom mud of lake Taihu and its assessment of potential ecological risk[J] . Journal of Nanjing Institute of Meteorology, 2006, 29 (5) : 700-705.

[9] WANG Sheng-qiang, SUN Jin-sheng, DING Hui, et al. Evaluation on potential ecological risk of sediment heavy metal pollution in Hai River[J].Environmental Engineering, 2005, 23 (2) : 62-64.

[10] WU Yong-feng, LIU Cong-qiang, TU Cheng-long, et al. The heavy metal pollution in urban soils of Guiyang City and their potential ecological hazard assessment[J]. Bulletin of Mineralogy, Petrology and Geochemistry, 2007, $3:$ 254-257.

[11] LIU Wen-xin, LUAN Zhao-kun, TANG Hong-xiao. Environmental assessment on heavy metal pollution in the sediments of leanriver with potential ecological risk index[J]. Acta Ecologica Sinica, 1999, 19 (2) : 206-211.

[12] Lars Hakanson. An ecological risk index for aquatic pollution controlAsedimentological[J]. Approach Water Research, 1980, 14 : 975-1000.

[13] YANG Zhen, HU Ming-an, HUANG Song. Heavy metals pollution in stream sediments and potential ecological risk assessment in dabaoshan mining area[J]. Journal of Guilin University of Technology, 2007, 27 ( 1) : 44-48

[14] Baker A J M, brooks R R, Pease A J, et al. Studies on copper and cobalt tolerance in three closey related taxa with in the genus Science from Zaire[J]. Plant and Soil, 1983, $73: 377-385$.

[15] AN Zhi-zhuang, CHEN Tong-bin, LEI Mei. Tolerance of Pteris vittata L. to $\mathrm{Pb}, \mathrm{Cu}$ and $\mathrm{Zn}[\mathrm{J}]$. Actc Ecologica Sinica, 2007, 27 (1) : 44-48.

[16] Books R R, Lee J, Reeves R D, et al. Detection of nickeliferous rocks by analysis of herbarium specimens of indicator plants[J]. Journal of Geochemical Exploration. 1977, 7 : 49-57.

[17] Salt E D, Blaylock M B, Kumar N P B A, et al. Phytore-mediation : A novel strategy for the removal of toxic metals from the environment using plants[J]. Biotechnology, 1995, $13: 468-474$.

[18] WU Zhi-qiang, GU SHANG-yi, LI Hai-ying, et al. Phytoremediation of heavy metals contaminated soils and hyper-accumulator's research advance[J]. Environmental Science and Management, 2007,32 (3) : 67-71.

[19] YUE Qing-ling. Study on heavy metal of soils and plants in mining in Hunan[D]. 2004.

[20] BI De, WU Long-hua, LUO Yong-ming, et al. Dominant plants and their heavy metal contents in six abandoned lead-zinc mine areas in Zhejiang Province[J]. Soils, 2006, 38 (5) : 591-597. 